\title{
TINJAUAN HERMENEUTIS TERHADAP HADIS KEPEMIMPINAN PEREMPUAN DALAM ISLAM
}

\author{
Wahyudi $^{1}$, Nur Fadilah ${ }^{2}$ \\ ${ }^{1}$ Institut Agama Islam Ma’arif NU (IAIMNU) Metro Lampung \\ ${ }^{2}$ Institut Agama Islam Negeri (IAIN) Kediri \\ *CORRESPONDENCE: $\square$ wahyudiragil447@gmail.com
}

Abstract

This paper discusses the hermeneutical perspective of the prohibition for Article History women to become leaders hadith narrated by Abu Bakrah. The factor that Received:14-11-2018, became the background of this study is that there are still many people who Revised :27-12-2018, understand that women are the second creature, namely "konco wingking". So, Accepted:28-12-2018 they are not deserve to be a leader for people. One of the normative bases is the hadith narrated by Abu Bakrah. The textual-literal understanding of the hadith has implications for the role of women in the public sphere so that there needs to be someone who can answer and place women to their proper degree. This study uses a qualitative method with Schleiermacher hermeneutics approach.The results of this research are the Hadith about the ban on women becoming leaders who narrated by Abu Bakrah through grammatical hermeneutics and psychological perspective cannot be applied in General. Thus, there are no restrictions for women today to be a leader for the people because they currently have a different social background when the Hadith it comes.

\section{Abstrak}

Makalah ini membahas hadis larangan perempuan menjadi pemimpin yang diriwayatkan oleh Abu Bakrah melalui perspektif hermeneutis. Faktor yang menjadi latar belakang penelitian ini adalah masih banyak orang yang memahami bahwa perempuan adalah makhluk kedua, yaitu "konco wingking". Jadi, mereka tidak pantas menjadi pemimpin bagi manusia. Salah satu landasan normatif adalah hadis yang diriwayatkan oleh Abu Bakrah. Pemahaman tekstual-literal dari hadis memiliki implikasi untuk peran perempuan di ruang publik sehingga perlu ada seseorang yang dapat menjawab dan menempatkan perempuan pada tingkat yang tepat. Penelitian ini menggunakan metode kualitatif dengan pendekatan Hermeneutika Schleiermacher. Adapun hasil dari penelitian ini adalah hadits tentang larangan perempuan menjadi pemimpin yang diriwayatkan oleh Abu Bakrah melalui perspektif hermeneutika gramatikal dan psikologis Schleiermacher tidak dapat diterapkan secara umum. Dengan demikian, tidak ada larangan bagi perempuan saat ini untuk menjadi pemimpin bagi orang-orang karena saat ini mereka memiliki latar sosial yang berbeda ketika hadis itu datang.
Article Info

\section{Keywords:}

Leadership;

Women;

Schleiermacher

Hermeneutics;

\section{Histori Artikel}

Diterima: $14-11-2018$

Direvisi : 27-12-2018

Disetujui: 28-12-2018

\section{A. Pendahuluan}

Islam adalah agama yang dibangun atas dua dasar, yaitu Alquran dan as-Sunnah. Dalam memahami keduanya diperlukan kajian holistik. Salah satunya adalah dengan menggunakan pendekatan hermeneutis. Pengamalan terhadap keduanya merupakan hal yang mutlak dilakukan oleh umat muslim. Bahkan di dalam ajarannya tidak ada perbedaan antara mahluk satu dengan yang lainnya, antara laki-laki dan perempuan, kecuali yang membedakannya adalah keimanan dan ketakwaanya[1]. Dalam Alquran surat Al-Hujarat ayat 13 Allah SWT menjelaskan : 


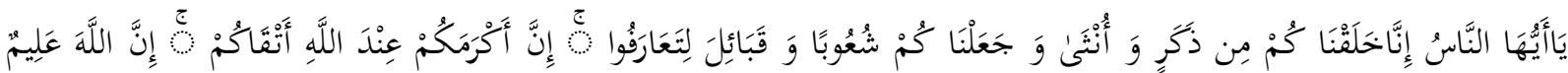

"wahai manusia sungguh kami telah menciptakan kamu dari seorang laki-laki dan seorang perempuan, kemudian kami jadikan kamu berbangsa-bangsa dan bersuku-suku agar kamu saling mengenal. Sungguh yang paling mulia di antara kamu di sisi Allah adalah yang paling bertaqwa, sungguh Allah Maha Mengetahui lagi Maha teliti”.

Jelas sekali terlihat, Allah tidak melebihkan salah satu di antara ciptaanya. Akan tetapi, pemahaman atas ayat-ayat di dalam Alquran serta Hadis, membuat sebagian pihak membatasi ruang lingkup perempuan, bahkan dijadikan dalil tentang larangan perempuan menjadi seorang pemimpin. Tidak sedikit yang menyimpulkan bahwa perempuan dianggap sesuatu yang negatif, bernilai rendah dan diremehkan[2]. Sehingga ketika dihadapkan dengan sebuah realita mengenai kepemimpinan perempuan, banyak dari para pakar tafsir dan hadis baik dari kalangan salaf maupun modern yang mempermasalahkannya dan memperdebatkannya hingga saat ini. Masing-masing kelompok mencari justifikasi pemikiran mereka dalam Alquran maupun hadis.

Perempuan pada era pra-Islam dianggap tidak patut mendapatkan kehormatan. Pandangan perihal ini tidak hanya terjadi di masyarakat pra Islam di kawasan Timur Tengah, dikutip dalam undang-undang manu yang menyatakan bahwa perempuan sepanjang hidupnya tidak pernah memiliki hak-haknya sendiri. Dalam urusan domestik mereka tidak diberi kesempatan beraktualisasi apalagi dalam urusan publik. Namun ketika Islam datang, perempuan yang pada mulanya dapat diwariskan kini dia memperoleh hak waris. Sehingga keberadaan perempuan benarbenar diakui.

Akan tetapi realitasnya dalam sejarah Islam terdapat masa di mana ruang gerak perempuan di ranah publik masih sangat dibatasi. Hal ini merupakan efek dari memahami teks keagamaan secara skriptualis-tekstual. Dengan pemahaman skriptualis-tekstual sebagian ulama melarang perempuan memegang tanggung jawab dalam urusan publik. Terlebih ketika dia harus menduduki jabatan pemimpin pemerintahan, problematika ini menjadi perdebatan di kalangan ahli. Salah satu hadis yang menjadi polemik dikalangan ulama perihal ini adalah hadis yang berkaitan dengan cerita bint al-Kisra.

Sebenarnya sudah banyak tulisan yang membahas perihal kepemimpinan perempuan dalam Islam, baik dalam bentuk jurnal, skirpsi, tesis maupun buku. Ida Noviati misalnya yang menulis tentang dilema kepemimpian perempuan dalam Islam di Jurnal Studi Gender dan Anak pada tahun 2008. M. Zainuri menulis tesis dengan judul Partisipasi Politik Perempuan (Perspektif Tradisi Islam Lokal Kudus) yang diterbitkan oleh Universitas Diponegoro Semarang pada tahun 2007.Solahuddin Ismail pada tahun 2009 menulis makalah di Jurnal Usuluddin dengan judul pembentukan organisasi cemerlang; pandangan Islam dalam melantik perempuan, dan masih banyak lagi karya tulis bebas yang tersebar di dunia maya.

Berbeda dengan penelitan sebelumnya, dalam artikel ini penulis hanya fokus kepada hadis riwayat Abu Bakrah dan berupaya mendekati hadis tersebut dengan Hermeneutika Schleiermacher. Dalam perspektif Schleiermacher munculnya teks sangat dipengaruhi oleh keadaan psikologi author. Sementara psikologi author terkonstruk dari setting sosial yang mengitarinya. Memahami hadis Nabi tentang larangan pemimpin perempuan misalnya, langkah awal yang harus diambil adalah dengan memahami setting sosial ketika teks itu muncul. Sehingga dapat dipahami secara tepat apa motif yang melatar belakangi munculnya hadis tersebut. 
Kajian tentang peran perempuan di ranah publik masih sangat relevan untuk dihadirkan di tengah masyarakat Indonesia saat ini. Terlebih pada tahun 2019 Indonesia menggelar pemilihan umum serentak. Melalui karya tulis ini penulis berharap peran perempuan di ranah publik seperti politik misalnya, tidak dibatasi dengan dalih agama. Tidak ada lagi kampanye yang menjatuhkan calon legislatif berjenis kelamin perempuan dengan sentimen dan dalil-dalil agama. Sehingga pemimpin yang terpilih benar-benar berdasarkan kapasitas dan kapabilitas yang dimiliki.

\section{B. Metode Penelitian}

Jenis penelitian ini adalah penelitian kualitatif dengan menggunakan studi pustaka (library research) dan hermeneutika Schleiermacher sebagai pisau analisisnya. Adapun objek material yang dikaji adalah hadis larangan perempuan menjadi pemimpin yang diriwayatkan oleh Abu Bakrah. Dengan pendekatan Hermeneutika Schleiermacher penulis mencari original meaning dari teks hadis yang menjadi objek penelitian. Sehingga makna teks hadis tersebut dapat dikontekstualisasikan di masa sekarang. Karena penelitian ini adalah studi pustaka (library research) maka yang menjadi sumber data adalah literatur pustaka yang relevan dengan tema penelitian, baik dari jurnal, buku maupun karya ilmiah lainnya.

\section{Pembahasan atau Analisis}

Salah satu hadis yang dijadikan argumen larangan perempuan sebagai pemimpin adalah hadis riwayat Abu Bakrah:

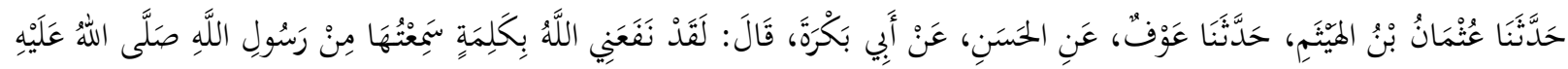

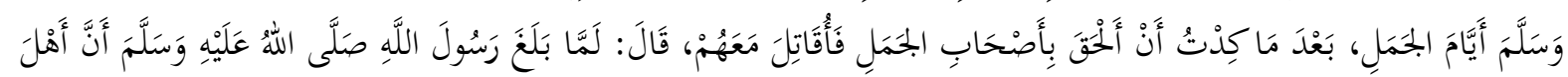

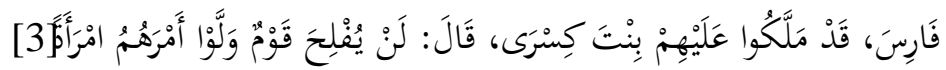

"Telah menceritakan kepada kami Uthmān bin Amr bin Haitham telah menceritakan kepada kami 'Auf dari Al Hasan dari Abū Bakrahmengatakan : Allah memberikan manfaat kepadaku dengan sebuah kalimat yang aku dengar dari Rasulullah SAW pada hari perang Jamal, setelah aku hampir membenarkan mereka Ashābal-Jamal dan berperang bersama mereka, ketika sampai kabar kepada Rasulullah SAW bahwa bangsa Persia mengangkat putri Kisra sebagai pemimpin, beliau bersabda: Tidak akan beruntung suatu kaum yang menyerahkan urusan (pemerintahan) mereka kepada seorang wanita”

Hadis di atas merupakan respon Nabi atas diangkatnya bint Kisra menjadi pempimpin pengganti ayahnya yang meninggal dunia. Karena kerajaan yang menghendaki demikian. Bagi ulama yang memahami secara tekstual, mereka melakukan generalisasi bahwa haram hukumnya seorang perempuan menjadi kepala pemerintahan. Sehingga bagaimanapun keadaannya perempuan tidak boleh menduduki pemimpin di ranah publik[4].

Di literatur klasik seperti Fatḥ al-Bāry dan Irshad al-Sāry di dalamnya lebih banyak menjelaskan siapa yang dimaksud dengan Kisra dan anak perempuan yang menggantikannya. Selain juga dibahas tentang kaitan hadis ini dengan surat yang pernah dikirim oleh Nabi kepada raja Kisra. Dalam kedua buku tersebut dijelaskan polemik yang terjadi di internal kerajaan Kisra, yang dalam buku karya al-Qasțalāni dinyatakan sebagai jawaban Allah atas doa Nabi Muhammad karena kesombongan Raja Kisra telah merobek-robek surat dari Nabi[5].

Meskipun sebagian besar dua karya klasik tersebut membahas hadis dari segi historinya, namun juga disinggung sedikit mengenai hukum menjadikan perempuan sebagai pemimpin. Mayoritas cendekiawan (berdasarkan kedua literatur tersebut) sepakat bahwa perempuan tidak diperbolehkan menjabat sebagai pemimipin dan menjadi qạ̣i . Pendapat ini dikutip Ibn Hajar dari al-Khațāby, 
dengan dasar-dasar argumen yang bersifat fiqhiyah, salah satu argument yang diungkapkan adalah perempuan tidak dapat menikahkan dirinya sendiri, mereka membutuhkan wali untuk menikahkan dirinya. Sementara al-T abary memperbolehkan perempuan menjadi pemimpin dalam ranah hukum, namun dia tidak menjelaskan landasan argumentasinya sehingga sampai pada kesimpulan ini[6].

Para pakar berbeda pendapat dalam menanggapi hadis di atas. Satu kelompok melarang perempuan menjadi pemimpin di ranah publik. Sementara kelompok yang lain memperbolehkannya. Sebab timbulnya berbagai perbedaan pendapat tersebut berawal kepada pemahaman terhadap sekumpulan dalil-dalil agama sebagai berikut:[7] (1) Nas Alquran. Salah satu yang menjadi objek perdebatan para pakar perihal kepemimpinan perempuan adalah ayat Alquran surat An-Nisa' ayat 34. Ada dua pemahaman yang diambil, pertama kepemimpinan hanya terbatas oleh kaum laki-laki saja, karena di dalam ayat tersebut sudah sangat jelas kepemimpinan adalah milik kaum laki-laki. Kedua, kelompok yang berpendapat bahwa jalinan antara laki-laki dan perempuan di dalam masalah umum merupakan hubungan kekuasaan. Penyebutan derajat kepemimpinan dalam Alquran tidak lain hanyalah dalam konteks kehidupan suami istri yang seharusnya dikaitkan dengan satu persoalan saja. (2) Sunnah Nabi saw. Setidaknya ada dua ketegori sunnah yang menjadi sumber perbedaan pendapat di kalangan pakar. Pertama Sunnah Quliyyah, tentang ungkapan yang disampaikan Rasulullah "suatu kaum tidak akan mendapatkan kemenangan jika menyerahkan urusan mereka kepada seorang perempuan". Sebagian kelompok menyatakan hadis ini diperuntukan untuk seluruh perempuan dalam bentuk kekuasaan. Kelompok lain menyatakan hadis tersebut menyangkut kekuasaan kekhalifahan tidak menyangkut kekuasaan lain dan ada pula kelompok ulama modern yang memungkiri kesahihan hadis tersebut. Kedua Sunnah Fi'liyyah, dalam tinjaun historis memang pada periode pertama Islam wanita masih belum mendapatkan tempat untuk dihormati di ranah publik. (3) Teori Maslahat. Sebagian golongan menilai pemberian kekuasaan kepada wanita bertentangan dengan dua bentuk kemaslahatan. Pertama, bertentangan dengan kemaslahatan umat. Menurut pandangan kelompok ini perempuan memiliki kecenderungan untuk melakukan penyimpangan, dan tidak berlaku bijak dan seimbang. Kedua, bertentangan dengan kemaslahatan keluarga. Hal ini karena kesibukan perempuan dalam berbagai kekuasaan akan menyita waktu dan perhatiannya dalam mengurus urusan rumah tangga dan keluarganya. (4) Tindakan Pencegahan. Kelompok yang menentang pemberian kekuasaan kepada perempuan menyatakan, kekuasaan memerlukan kiprah pemegang kekuasaan secara langsung di lapangan. Sementara dalam pemahaman kelompok ini, wilayah perempuan hanya berada di sekitar rumah. Perempuan tidak diperbolehkan bergaul dan berinteraksi dalam kegiatan dengan laki-laki. Menurut mereka hal tersebut dilarang oleh syariat Islam.

Dari uraian tersebut, mereka yang tidak memperbolehkan perempuan dalam jabatan politik dikuatkan dengan dalil Alquran Surat An-Nisa' ayat 34. Meskipun ayat ini diturunkan hanya untuk konteks keluarga, akan tetapi menariknya dalam wilayah publik berdasarkan qaidah mafhum aulawiy yang menyimpulkan, dalam skala kecil seperti keluarga saja perempuan dipimpin oleh lakilaki, apalagi dalam konteks luas.

Sementara hadis Nabi yang diriwayatkan oleh Abu Bakrah ditinjau dari segi kebahasaan (fiqh lughah) menunjukan bahwa hadis tersebut bersifat dan berlaku umum. Sebab lafadz qawm di dalam hadis tersebut berbentuk isim nakirah dan jatuh setelah nafi. Sebagaimana kaidah yang menyatakan: 


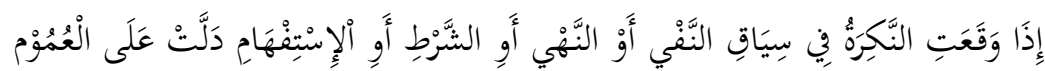

"Apabila isim nakirah terletak setelah teks nafi (peniadaan) atau nahi (larangan) atau syarat atau istifham (pertanyaan), maka ia menunjukkan makna umum"

Dengan demikian, bangsa manapun yang dipimpin oleh perempuan maka ia tidak akan beruntung. Ini sejalan dengan kaidah al-'ibrah bi 'umūm al-lafaz lā bi khusūs al-sabāb, yang dijadikan ibrah adalah keumuman lafadznya bukan kekhususan sebabnya. Sehingga pendapat yang menyatakan bahwa perempuan tidak diperbolehkan menjadi pemimpin semakin kuat. Hal ini dikarenakan, meskipun secara historis hadis ini disampaikan karena respon Nabi terhadap pengangkatan putri Kisra sebagai pemimpin kerajaan tersebut, namun arti "Qawm" dalam hadis tersebut tidak hanya terkhususkan kepada komunitas Persia saja, melainkan berlaku umum, bagi siapapun yag menyerahkan kepemimpinan kepada perempuan.

Menurut Al-Khattabi, di dalam hadis ini mengisyaratkan bahwasanya bagi seorang perempuan tidak boleh menjadi pemimpin ataupun seorang hakim. Dengan alasan perempuan tidak mampu menikahkan dirinya sendiri sebagaimana perempuan tidak bisa untuk menikahkan perempuan lain[5].

Al-Baghawy dalam karyanya Sharhal Sunnah menyatakan bahwa ulama sepakat perempuan tidak diperbolehkan menjadi pemimpin maupun hakim (qadi). Karena seorang imam atau pemimpin perlu keluar untuk mengurusi permasalahan jihad (perang) dan urusan kaum muslimin. Sedangkan wanita adalah aurat, tidak boleh keluar (dari rumahnya). Wanita sering kali tidak mampu mengurusi banyak perkara karena kelemahannya dan dikarenakan wanita itu kurang (agama dan akalnya). Padahal kepemimpinan dan kehakiman itu adalah jabatan yang sempurna, tidak boleh dijabat kecuali oleh kaum lelaki yang sempurna[8].

M. Abduh (1849-1905) seorang tokoh muslim yang notabne merupakan perintis gerakan modern ternyata masih berpegang teguh pada pemikiran dan pendapat mayoritas ulama klasik, yang tidak memperbolehkan perempuan menjadi pemimpin. Pendapat ini dilandasi dengan ayat Alquran surat an-Nisa' ayat 34 :

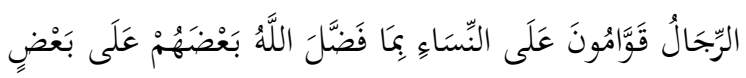

Penggalan ayat bi mā faḍ̂l Allah ba'ḍhum 'ala ba'ḍ menunjukan kelebihan jenis laki-laki dibandingkan jenis perempuan secara umum bukan secara perorangan. Adapun dalam kenyataan terdapat perempuan yang memiliki kapasitas dan kapabilitas yang lebih sebagai pemimpin dibandingkan kebanyakan kaum laki-laki, hal tersebut tidak dapat dijadikan argumen diperbolehkannya perempuan sebagai pemimpin secara umum.

Namun ada sebagain pakar yang memahami ayat tersebut berbeda dengan M. Abduh dan mayoritas ulama klasik. Kata bi mā faḍ̣l Allah ba'ḍhum 'ala ba'ḍ bukan menunjukan laki-laki memiliki kelebihan dibanding dengan perempuan, akan tetapi sebagian laki-laki maupun perempuan mereka memiliki kelebihan di atas jenis mereka masing-masing. Dengan pemahaman ini maka damirhum pada ayat di atas tidak hanya menyimpan kata al-rijal tetapi juga al-nisa'. Sehingga tidak ada superioritas laki-laki di atas perempuan. Pendapat ini lebih diterima oleh para penggiat keadilan dan kesetaraan gender.

Pada tahun 1952 ulama Mesir mengeluarkan fatwa yang membagi kewenangan perempuan dalam dua kategori. Pertama kewenangan privat (al-walayat al-khașah) dalam kewenangan ini baik keluarga maupun suaminya tidak berhak mengitervensi perempuan, yang termasuk dalam kewenangan ini adalah dalam hak mengelola harta pribadinya. Adapun dalam masalah publik (al- 
walayat al-'ammah) seperti menjadi anggota perleman yang ikut andil dalam membentuk dan menetapkan undang-undang dan mengawasi pelaksanaannya masih menjadi hak preogratif kaum laki-laki, dan itupun bagi yang memenuhi syarat-syarat tertentu. Namun ternyata dalam perkembangan selanjutnya ulama Mesir memperbolehkan perempuan ikut andil dalam kancah dunia perpolitikan[9].

Adapun diantara ulama yang memperbolehkan perempuan menjadi pemimipin memahami hadis tersebut secara kontekstual dan beberapa argumennya adalah: (1) Dr. Muhammad Sayid T. anțawī, Shaikh Al-Azhār yang berpendapat sebagai berikut:

"Wanita yang menduduki posisi jabatan kepala negara tidaklah bertentangan dengan syariah karena Alquran memuji wanita yang menempati posisi ini dalam sejumlah ayat tentang Ratu Balqis dari Saba. Dan bahwasanya apabila hal itu bertentangan dengan syariah, maka niscaya Alquran akan menjelaskan hal tersebut dalam kisah ini. Adapun tentang sabda Nabi bahwa "Suatu kaum tidak akan berjaya apabila diperintah oleh wanita" Tantawi berkata: bahwa hadis ini khusus untuk peristiwa tertentu yakni kerajaan Persia dan Nabi tidak menyebutnya secara umum. Oleh karena itu, maka wanita boleh menduduki jabatan sebagai kepala negara, hakim, menteri, duta besar, dan menjadi anggota lembaga legislatif. Hanya saja perempuan tidak boleh menduduki jabatan Shaikh Al-Azhār karena jabatan ini khusus bagi laki-laki saja karena ia berkewajiban menjadi imam shalat yang secara syariah tidak boleh bagi wanita"

Selanjutnya adalah (2) Yūsuf Al-Qordhāwì yang menyatakan bahwa "perempuan berhak menduduki jabatan kepala negara (riasah daulah), mufti, anggota parlemen, hak memilih dan dipilih karena sikap Islam dalam soal ini jelas bahwa wanita itu memiliki kemampuan sempurna (tamām al-aḥliyah)[10]", (3) Imam al-Thabari yang mengatakan "wanita boleh menjabat sebagai hakim (pemimpin) secara mutlak" [11]. (4) Muhammad Syaltut menjelaskan bahwasannya antara laki-laki dan perempuan mempuanyai tabi'at yang sama, karena Tuhan telah menganugrahkan kepada perempuan sebagaimana menganugrahkan kepada laki-laki, berdasarkan potensi dan kemampuan dalam memikul tanggung jawab atas berbagai kegiatan baik umum maupun khusus. Maka dari itu syariat menempatkan keduanya dalam satu kerangka yang sama.[12]

Di antara argumen yang diungkapan oleh para cendikiawan muslim dalam menerima kepemimpinan perempuan adalah; (1) tidak ada satupun nash Quran dan hadis yang melarang wanita untuk menduduki jabatan apapun dalam pemerintahan, (2) Surat An-Nisā ayat 34 hanya berkaitan dengan kepemimpinan keluarga, (3) Perempuan dan laki-laki sama sebagai kholifah, (4) Perempuan juga bertanggung jawab membangun pemerintah sebagaimana yang disinyalir dalam Surat At-Taubah ayat 71:

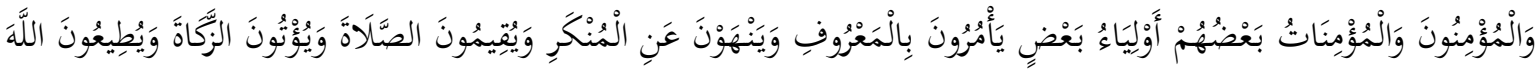

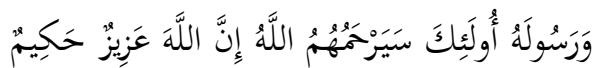

"Dan orang-orang yang beriman, lelaki dan perempuan, sebahagian mereka (adalah) menjadi penolong bagi sebahagian yang lain. mereka menyuruh (mengerjakan) yang ma'ruf, mencegah dari yang munkar, mendirikan shalat, menunaikan zakat dan mereka taat pada Allah dan Rasul-Nya. mereka itu akan diberi rahmat oleh Allah; Sesungguhnya Allah Maha Perkasa lagi Maha Bijaksana"

Amar ma'ruf nahi munkar adalah sebuah kewajiban yang mencakup berbagai perjuangan, baik laki-laki dan perempuan di antara terlibatnya di dalam kehidupan politik bermasyarakat. Dikutip dari seorang ulama golongan kedua yang teguh memegang ajaran salaf Sa'id Ramdhan alButhi mengungkapkan bahwasanya " seorang perempuan boleh menjadi anggota legislatif, akan tetapi tidak boleh menjadi kepala negara ( al-imamah al-kubro)". Terbukti dari sejarah bahwasanya ketika itu Umar bin Khatab pernah menugaskan seorang perempuan untuk menjadi bendahara pasar. Sebagaimana telah dikatakan pula dari Ibn Hazm khusus untuk jabatan kepala negara 
perempuan tidak boleh menduduki jabatan tersebut, alasan yang diungkapkan bukan saja karena hadis nabi sebagai pendukungnya, akan tetapi juga dilihat dari analisis sudut pandang hukum dan psikologisnya[13], (5) Alquran mengisahkan adanya kerajaan yang dipimpin oleh seorang wanita, Allah berfirman dalam surat An-Naml ayat 22-23, (6) Larangan keluar rumah dalam Surat AlAhzab ayat 33, lebih ditujukan pada mereka yang keluar rumah dengan mengumbar aurat (tabarrujal jahiliyah). Karena itu, fikih sebenarnya membolehkan wanita keluar rumah untuk bermuamalah dengan ketentuan menutup auratnya. Seperti yang diungkapkan oleh Abu al-A'la alMaududi, perempuan boleh-boleh saja keluar rumah jika mempunyai keperluan dan sepanjang mampu menjaga kesucian diri dan menahan rasa malu. Menurut Al-Qurthubi menegaskan, agama dipenuhi oleh tuntutan agar perempuan tidak keluar rumah kecuali dalam keadaan darurat. Menurut Yūsuf Al-Qardhawi, Islam tidak melarang Perempuan bekerja di luar rumah selama memenuhi beberapa persyaratan diantara: Pertama, pekerjaan itu tidak dilarang syariah. Wanita tidak boleh melakukan pekerjaan yang dilarang syariah sebagaimana hal itu tidak boleh bagi laki-laki. Akan tetapi ada juga jenis pekerjaan yang boleh bagi laki-laki tapi tidak boleh bagi perempuan. Misalnya, wanita tidak boleh menjadi penari, atau sekretaris pribadi bagi laki-laki yang berada di dalam kamar tertutup. Karena wanita yang khalwat [berduaan dalam ruangan tertutup] dengan lelaki lain tanpa ditemani suami atau mahram adalah haram secara pasti menurut ijma' ulama.

Kedua, pekerjaan yang dilakukan hendaknya tidak meniadakan tugas wanita yang utama yaitu sebagai istri dengan melaksanakan hak-hak rumah tangga dan sebagai ibu dalam memenuhi hakhak anak. Sekiranya pekerjaan tersebut akan mengganggu tugas-tugas utamanya, maka itu tidak bisa diterima.

Ketiga, berpegang teguh pada etika Islam. Seperti tata cara keluar rumah, berpakaian, berjalan, berbicara, dan menjaga gerak-geriknya. Oleh karena itu, wanita tidak boleh keluar tanpa mengenakan busana muslim, atau memakai parfum supaya wanginya tercium laki-laki. Perempuan juga tidak boleh berjalan dengan gaya jalan seperti yang digambarkan Allah dalam QS An-Nur 24:31 "dan janganlah mereka memukulkan kakinya agar diketahui perhiasan yang mereka sembunyikan." Sebagaimana tidak dibolehkan berbicara kecuali untuk kebaikan seperti disebut dalam QS Al-Ahzab 33:32 "Maka janganlah kamu tunduk dalam berbicara sehingga berkeinginanlah orang yang ada penyakit dalam hatinya dan ucapkanlah perkataan yang baik". Inilah etika prinsip yang harus dijaga oleh wanita yang bekerja di luar rumah.

Quraish Shihab berusaha mendamaikan mengenai dua perdebatan pendapat mengenai larangan dan diperbolehkannya perempuan menjadi pemimpin. Dengan argumennya bahwa, sebagian ulama dan pemikir pada masa lalu tidak membenarkan seorang perempuan menjadi atau terlibat dalam politik dan sebuah jabatan kepala Negara dikarenakan situasi dan keadaan pada waktu itu, dimana kondisi perempuan yang belum siap menduduki jabatan, dan di anggapnya seorang perempuan yang lemah sehingga tidak mampu dalam mengemban sebuah kepemimpinan. Berbeda dengan realitas saat ini, karena fatwa, pandangan ulama dan para ahli fasir mengalami perubahan kondisi dan situasi, disitulah terjadi pengembangan penafsiran dan tidak relevan lagi jika melarang perempuan terlibat dalam politik atau kepemimpinan perempuan, selama mampu dan memenuhi kriteria seorang pemimpin[14].

Menurut para pakar ushul fiqh suatu lafal nas dapat dikatakan sebagai larangan atau haram setidaknya memuat empat hal: (1) Secara redaksional, naṣ dengan tegas menunjukan haram, (2) Larangan tersebut diungkapkan dalam bentuk nahi, (3) Naṣ mengandung ancaman ('uqūbah), (4) 
Menggunakan redaski lain yang menurut gramatikal Arab menunjukan kepada tuntutan yang harus dilaksanakan[15].

Dengan berdasarkan kaidah ini maka hadis riwayat Abu bakrah tersebut tidak dapat dijadikan sebagai dalil larangan perempuan sebagai pemimpin pemerintahan. Selain itu, maksud hadis di atas adalah penyerahan secara totalitas urusan pemerintahan kepada perempuan. Hibah Rauf Izzat menyatakan bahwa hadis yang diiriwayatkan oleh Abu Bakrah berkedudukan shohih, akan tetapi tidak dapat dimaknai sebagai larangan terhadap kepemimpinan politik perempuan. Kata amr pada hadis di atas dipahami oleh para cendiawan yang pro-pemerintahan perempuan sebagai penyerahan kekuasaan secara totalitas. Sedang pengendalian secara total menimbulkan pemerintahan yang diktator absolut, yang jelas bertentangan dengan syariat.

Dengan demikian dapat dipahami bahwa yang termasuk dalam larangan hadis di atas adalah menyerahkan urusan pemerintahan secara mutlak dan totalitas kepada perempuan. Adapaun pengangkatan perempuan menjadi pemimpin negara yang melibatkan berbagai elemen lain yang sesuai dengan asas demokrasi dan shüra maka tidak termasuk dalam kategori yang dilarang oleh hadis di atas.

\section{Pendekatan Hermeneutis Schleiermacher Terhadap Hadis Kepemimpinan Perempuan}

Secara hermeneutis teks tidak bisa lepas dari pengaruh konteks historis yang meliputinya. Hermeneutika romantik (salah satu tokohnya Schleiermacher) misalnya berupaya mencari makna objektif dari penggagas teks (author) dengan dua rekonstruksi. Pertama melalui rekonstruksi historis-objektif. Dalam rekonstruksi historis-objektif penafsir berupaya membahas hubungan bahasa secara komprehensif dengan pendeketan linguistik. Kedua melalui rekonstruksi historissubjektif yang bermaksud membahas perihal masuknya pernyataan dalam pikiran seseorang dengan cara analisis psikologi penggagas.

Hermeneutika Schleiermacher ini menemukan relevansinya ketika dihadapkan dengan hadis kepemimpinan perempuan di atas. Selain tinjau dari perspektif linguistik hadis tersebut juga perlu dianalisis bagaiamana psikologi Nabi ketika menyampaikan hal tersebut. Tentu psikologi penggagas (author) sangat terpengaruh oleh konstruksi dan setting sosial yang meliputinya. Sehingga memahami konstruksi sosial sangat penting guna memperoleh pemahaman kondisi psikologi penggagas teks (author).

Dalam tradisi kerajaan Kisra, pemimpin negara selalu dipegang dan diserahkan kepada lakilaki. Sehingga pengangkatan perempuan (bint Kisra) merupakan tindakan yang kontradiktif dengan tradisi. Sebab derajat perempuan di era tersebut berada di bawah bayang-bayang lelaki. Ruang gerak perempuan sangat dibatasi sehingga mereka tidak diberikan ruang untuk mengurus persoalan publik terlebih urusan negera. Pandangan seperti ini tidak hanya terjadi di kerajaan Kisra akan tetapi juga merambah keseluruh Jazirah Arab[16].

Stereotipi terhadap peran perempuan di ranah publik telah terjadi jauh sebelum Islam datang. Jazirah Arabia di masa lalu (sebelum Islam datang) merupakan wilayah yang berada di antara dua kerajaan besar. Di bagian Barat terdapat kerajaan besar yang berpusat di Roma kemudian pindah ke Binzatium. Sementara sebelah timur Jazirah Arab terdapat kerajaan Sasania yang berlangsung pada kisaran tahun 234-634 H[17]. Dalam masa ini perempuan dianggap sebagai manusia kelas kedua (second class) setelah laki-laki. Sebab hukum yang berlaku pada masa ini merupakan perpaduan antara warisan nilai-nilai Mesopotamia dan nilai-nilai Religius yang diambil dari kitab suci, seperti dalam Kitab Perjanjian lama, perjanjian baru, terutama dalam pasal-pasal 
kitab kejadian dan lebih terperinci dalam kitab Talmud. Semua keterangan dalam kitab tersebut seolah-olah menepatkan perempuan dalam jenis kelamin kedua yang harus tunduk kepada otoritas laki-laki[18].

Pola relasi gender di masyarakat Arab tidak jauh berbeda dengan masyarakat sekitarnya. Dalam masyarakat Yunani dan Romawi kepala rumah tangga secara mutlak berada dalam kekuasaan laki-laki. Laki-laki secara mutlak memegang kekuasaan dalam bidang hukum, ekonomi bahkan budak yang berada dalam keluarga tersebut. Konsepsi seperti ini juga dilakukan oleh masyarakat Arab[19], bahkan sebagian kabilah Arab mengubur hidup-hidup bayi perempuannya karena dianggap sebagai aib keluarga. Ideologi patriarki seperti ini memberikan otoritas penuh bagi laki-laki baik dalam kehidupan berumah tangga maupun dalam wilayah publik. Sementara perempuan nyaris tidak diberikan ruang di ranah publik, ia hanya menjadi "konco wingking" yang berurusan dengan tugas-tugas reproduksi, rumah tangga atau di kemah-kemah (wilayah domestik)[18].

Dengan setting sosial, politik dan sistem nilai seperti di atas, peran perempuan yang sangat terbatas bahkan nyaris tidak ada peran di ranah publik. Maka bukanlah hal yang mengherankan Rasulullah bersabda demikian. Sebab secara psikologi Rasulullah tentu terkonstruk dan terpengaruh dengan sistem nilai yang berkembang saat itu. Hadis tersebut merupakan respon Rasulullah terhadap kenyataan perempuan saat itu, yang secara sosial maupun kultural merupakan makhluk yang lemah. Sehingga dengan kondisi perempuan yang seperti tersebut (tidak berdaya) tentu tidak layak dan tidak mungkin akan meraih kesuksesan ketika diberi tugas memimpin negara atau kerajaan pada saat itu.

Dengan demikian, penolakan tersebut bukan didasarkan pada putri Kisra seorang perempuan, akan tetapi didasarkan kepada ketidak mampuannya dalam pemerintahan. Fatima Mernissi telah mengkritik hadis tersebut dari segi sanad dan matannya. Serta pertanyaan mengapa hadis tersebut dikeluarkan pada saat terjadi kemelut politik dalam perang Jamal antara Aisyah dan Ali-Bin Abi-thalib setelah 23 tahun wafatnya Rasulullah, dimana Abu Bakrah berpihak kepada Ali[20].

Sementara itu, Amina Wadud dengan pendekatan hermeneutiknya berargumen bahwa interpretasi teks kegamaan memiliki nilai yang begitu relatif, dan tidak ada penafsiran yang benarbenar objektif. Menurutnya teks agama harus didekati dengan metode kritik historis. Artinya dalam sebuah penafsiran hendaknya memperhatikan latar belakang budaya yang dimiliki suatu bahasa dan yang membedakan antara unsur normatif dan kontekstualnya (dalam istilah hermeneutika romantis masuk dalam ranah analisi psikologi (author). Menurutnya kontroversi yang timbul mengenai diskriminasi penolakan terhadap perempuan bukan berasal dari teks Alquran dan Hadis nabi yang membatasi perempuan, akan tetapi penafsiran terhadap itu sendirilah yang akhirnya menyebabkan perdebatan[21].

Perkembangan kebudayaan dan sistem nilai sosial yang berlangsung di tengah-tengah masyarakat juga turut andil dalam memberikan berbagai perubahan. Terutama perubahan yang dibawa oleh Islam, yang secara bertahap memberikan perubahan terhadap status dan kedudukan perempuan. Perubahan tersebut pada gilirannya memberikan pengaruh terhadap pemaknaan terhadap peran perempuan, baik dalam ranah privat terlebih dalam wilayah publik. Sehingga dengan keadaan sosial dan sistem nilai sosial saat ini, teks-teks agama yang berhubungan dengan peran perempuan harus diinterpretasi ulang agar tidak terjadi kesan seolah-olah agama Islam membatasi ruang gerak perempuan. 


\section{Kesimpulan}

Melalui analisis Hermeneutika Schleirmacher, hadis di atas bukanlah larangan mutlak bagi perempuan untuk menjadi pemimpin di ranah publik. Sebab teks hadis tersebut merupakan respon Nabi terhadap perempuan di masa itu, sehingga tidak bisa dijadikan patokan umum. Apalagi wanita saat ini juga mempunyai kesempatan dan hak yang sama dalam hal pendidikan dengan kaum lakilaki. Kaum perempuan tidak lagi termarginalkan sebagaimana ketika teks tersebut muncul.

Kontekstualisasi teks-teks hadis misoginis mutlak dibutuhkan. Hal ini agar kaum perempuan tidak selalu dianggap sebagai makhluk kedua setelah laki-laki. Sehingga perempuan memiliki peran yang sama di ranah publik yang sama dengan kaum laki-laki. Pandangan ini selaras dengan banyak ayat Alquran yang menyatakan bahwa kaum perempuan memiliki kedudukan yang sama dihadapan Tuhan. Pembatasan terhadap peran perempuan memang dipengaruhi oleh banyak faktor, salah satu yang dominan adalah pemahaman yang literal terhadap teks agama. Sehingga mutlak diperlukan kontesktualisasi pemahaman salah satunya melalui pendekatan hermeneutika.

\section{Daftar Pustaka}

[1] S. M. Mulia, Islam dan Inspirasi Kesetaraan Gender. Yogyakarta: Kibar Press, 2000.

[2] L. S. Thahir, Studi Islam interdisipliner: aplikasi pendekatan filsafat, sosiologi, dan sejarah, Cet. 1. Yogyakarta, Indonesia: Qirtas : Didistribusikan oleh Qalam, 2004.

[3] M. bin I. al-Bukha>ry, Słahih al-Bukha>ry. Bairut: Da>r Ibn Kathir, 2002.

[4] Y. Qardhawi, Fikih Dailah dalam Presepektif Al-Quran dan Sunnah. Jakarta: Pustaka AlKautsar, 1997.

[5] A. bin A. bin H. al-Asqalani, Fath Ba>ry Sharh\} S\}ahih al-Bukha>ry, vol. VIII, VIII vols. Bairut: Da>r Kutub al-Ilmiyah, 1989.

[6] A. bin M. al-Syafii, Irshad al-sa>ry Sharh\} S\}ahih al-Bukha>ry, vol. IX, IX vols. Beirut: Da>r Kutub al-Ilmiyah, 1996.

[7] H. R. Izzat, Wanita Dalam Politik Pandang Islam. Bandung: Remaja Rosdakarya Offset, 1997.

[8] A.-H. bin M. al-Baghawi, Sharh\} al-Sunnah, vol. V, V vols. Bairut: Da>r Kutub al-Ilmiyah, 1992.

[9] K. Salenda, "kepemimpinan perempuan dalam perspektif Islam," al-Risalah, vol. 12, no. 2, Nov. 2012.

[10] Y. al-Qardhawi, "Fikih Hayat." .

[11] I. Rushd, Bida >yah al-mujtah\}id wa Nih\}a >yah al-Muqtas $\}$ id, vol. I. Kairo: Da>rul H\} adith, 2004.

[12] M. Syaltut, Min Taujihad al-Islam. Kairo: Al-Idarah al-Amah li Al-Azhar, 1959.

[13] W. Masrurah, "KEPEMIMPINAN PEREMPUAN DALAM TAFSIR TEMATIK ALQUR'AN DAN HADITS," vol. 2, p. 18, 2017.

[14] H. Hasan, Tafsir Gender Studi Perbandingan Antara Tokoh Indonesia dan Mesir. Jakarta: Badan Litbang dan Diklat Departemen Agama, 2009.

[15] W. al-Zuhaily, Ushul Fiqh al-Islamy, vol. I. Bairut: Dar al-Fikr, 1998.

[16] I. Novianti, "Dilema Kepemimpinan Perempuan Dalam Islam," Yinyang: Jurnal Studi Islam, Gender dan Anak, vol. 3, no. 2, pp. 255-261, 2008.

[17] I. M. Lapidus, A History Of Islamic Societies. New York: Cambrige University Press, 1988.

[18] N. Yuslem, "Kontekstualisasi Pemahaman Hadis," MIQOT: Jurnal Ilmu-ilmu Keislaman, vol. 34 , no. 1, 2010.

[19] N. Umar, Argumen Kesetaraan Jender. Jakarta: Penerbit Paramadina, 1999.

[20] T. Tanggareng, "Kepemimpinan Perempuan alam Presepektif Hadits," KARSA: Journal of Social and Islamic Culture, vol. 23, no. 1, Jun. 2015. 
Fikri : Jurnal Kajian Agama, Sosial dan Budaya

Wahyudi, Nur Fadilah

[21] E. Dewi, "PEMIKIRAN AMINA WADUD TENTANG REKONSTRUKSI PENAFSIRAN BERBASIS METODE HERMENEUTIKA,” vol. 15, no. 2, p. 23, Oct. 2013. 
Fikri: Jurnal Kajian Agama, Sosial dan Budaya

Wahyudi, Nur Fadilah 